\title{
MANAJEMEN DALAM MENINGKATKAN MUTU LULUSAN SD NEGERI 2 PRINGSEWU BARAT
}

\author{
Flora Krisnawati, Yulianto \\ STIE Tribuana Bekasi, STKIP Muhammadiyah Pringsewu
}

\begin{abstract}
ABSTRAK
Penelitian ini bertujuan untuk mendeskripsikan mengenai manajemen dalam meningkatkan mutu lulusan di SD Negeri 2 Pringsewu Barat. Metode penelitian yang digunakan dalam penelitian ini adalah deskriptif kualitatif. Sumber data yang dipakai yaitu Kepala Sekolah, Wakil Kepala Sekolah dan guru. Hasil dari penelitian ditemukan bahwa perencanaan sudah sesuai dengan apa yang direncanakan oleh kepala sekolah. Selain itu, dalam pengorganisasian sudah terlihat jelas dalam mebrian tugas pada guru dan program sekolah. Dan selanjutnya, dalam pelaksanaan meliputi sarana dan prasarana, fasilitas yang mendukung pembelajaran, program, Kurikulum dan RPP. Terakhir, dalam monitoring dan evaluasi dilakukan secara teknis oleh pengawas sekolah, kepala sekolah dan masyarakat.
\end{abstract}

Kata kunci: manajemen, peningkatan, mutu, lulusan

\section{PENDAHULUAN}

Pendidikan bertanggung jawab menyiapkan SDM(SDM) yang baik untuk pembangunan Negera. Pembangunan selalu memiliki hubungan yang erat dengan kemajuan jaman dan selalu memunculkan pemasalahan baru yang tidak pernah dipikirkan sebelumnya namun harus tetap disikapi dengan bijak. Pemerintah berupaya memajukan kualitas SDM untuk mewujudkan pembangunan nasional diseluruh aspek kehidupan sebagaimana yang telah di amanatkan dalam pembukaan Undang-undang Dasar 1945 alinea ke-4 yaitu mencerdaskan kehidupan bangsa, merupakan bukti keseriusan para pendiri negara ini dalam meningkatkan SDM Indonesia yang mempunyai harkat dan martabat yang tinggi. Kemudian komitmen tersebut dituangkan dalam Batang Tubuh Undang-undang Dasar 1945 pada pasal 32 ayat 1 yang berbunyi bahwa setiap warga negara berhak mendapatkan pendidikan. Fokus dari dari UUD 1945 tersebut adalah peningkatan SDM Indonesia agar menjadi manusia yang punya harkat dan martabat yang mulia, bebas dari belenggu kebodohan. 
Indonesia memerlukan SDM dalam jumlah dan mutu yang memadai sebagai pendukung utama dalam pembangunan. Untuk memenuhi SDM tersebut, pendidikan memiliki peran yang sangat penting. Hal ini sesuai dengan UU No 20 Tahun 2003 tentang Sistem Pendidikan Nasional pada Pasal 3 , yang menyebutkan bahwa pendidikan nasional berfungsi mengembangkan kemampuan dan membentuk karakter serta peradaban bangsa yang bermartabat dalam rangka mencerdaskan kehidupan bangsa.

Amanah UU Sistem Pendidikan Nasional tahun 2003 tersebut bermaksud agar pendidikan tidak hanya membentuk insan Indonesia yang cerdas, namun juga berkepribadian, sehingga nantinya akan lahir generasi bangsa yang tumbuh berkembang dengan karakter yang bernafaskan nilainilai luhur bangsa serta agama. Pendidikan memegang peran yang sangat penting dalam proses peningkatan kualitas sumber daya manusia. Peningkatan kualitas pendidikan merupakan suatu proses yang terintegrasi dengan proses peningkatan kualitas SDM itu sendiri.
Menyadari pentingnya proses peningkatan kualitas sumber daya manusia, maka kalangan swasta samasama telah dan terus berupaya mewujudkan amanat tersebut melalui berbagai usaha pembangunan pendidikan yang lebih berkualitas antara lain melalui pengembangan dan perbaikan kurikulum dan sistem evaluasi, perbaikan sarana pendidikan, pengembangan dan pengadaan materi ajar, serta pelatihan bagi guru dan tenaga kependidikan lainnya.

Sekolah adalah salah satu institusi yang mempunyai fungsi srategis dalam upaya meningkatkan sumber daya manusia. Sebab sekolah adalah lingkungan hidup anak untuk mendapatkan pendidikan yang terprogram dan sistematis.

Memasuki abad XXI, tantangan besar yang dihadapi oleh seluruh bangsa pada era yang oleh banyak orang disebut sebagai era globalisasi saat ini adalah ketatnya kompetisi di berbagai bidang. Kompetisi ini akan memasuki seluruh dimensi kehidupan dan menjamah wilayah geografis di berbagai belahan dunia. Berbagai macam produk dan jasa (barang dan 
bahkan SDM ) dari satu negara akan menyerbu masuk ke negara-negara lain. Jika ingin dapat survive atau bahkan menjadi pemenang dalam era kompetitif ini, maka kepemilikan daya saing menjadi prasyarat mutlak yang tidak dapat ditawar lagi

Perkembangan ilmu pengetahuan dan teknologi telah membawa perubahan di hampir semua aspek kehidupan manusia dimana berbagai permasalahan hanya dapat dipecahkan kecuali dengan upaya penguasaan dan peningkatan ilmu pengetahuan dan teknologi. Selain manfaat bagi kehidupan manusia di satu sisi perubahan tersebut juga telah membawa manusia ke dalam era persaingan global yang semakin ketat. Agar mampu berperan dalam persaingan global, maka sebagai bangsa kita perlu terus mengembangkan dan meningkatkan kualitas sumber daya manusianya. Oleh karena itu, peningkatan kualitas SDM merupakan kenyataan yang harus dilakukan secara terencana, terarah, intensif, efektif dan efisien dalam proses pembangunan, kalau tidak ingin bangsa ini kalah bersaing dalam menjalani era globalisasi tersebut.
Untuk mencapai amanah UUD dan UU sistem pendidikan maka sekolah perlu menetapkan manajemen dalam peningkatan mutu output yang akan dihasilkan. Kepala sekolah adalah sosok kunci yang menentukan terwujudnya berbagai standar pengelolaan satuan pendidikan sebagaimana disebutkan di atas. Kepala Sekolah sebagai Manajer pengambilan berbagai keputusan strategis menjadi prasyarat keberhasilan pengembangan sekolah. Untuk itu kepala sekolah harus mampu membangun kemandirian sekolah melalui penguatan dan manajemen untuk peningkatan mutu lulusan.

Untuk mewujudkan tujuan nasional dalam peningkatan mutu lulusan, setiap sekolah sangat membutuhkan manajemen yang baik dalam melaksanakan kegiatannya. Dengan manajemen yang baik dapat dipergunakan sebagai alat untuk mengarahkan kegiatan sekolah dan dapat dipergunakan sebagai patokan yang harus dipegang oleh semua pihak warga sekolah untuk mencapai tujuan. Manajemen peningkatan mutu lulusan di SDN 2 Pringsewu Barat. 
Perlu dicatat bahwa semua sekolah, apapun bentuknya, berdiri atau didirikan atas dasar asumsi, keyakinan, sistem nilai dan mandat tertentu. Dalam kaitannya dengan perencanaan pengembangan, dasar-dasar keberadaan ini disebut dengan premis lembaga atau premis sekolah. Premis-premis sekolah itu biasanya disajikan dalam bentuk rumusan visi, misi, dan nilai-nilai fundamental organisasi. Visi dapat dipandang sebagai alasan atas keberadaan lembaga dan merupakan keadaan "ideal" yang hendak dicapai oleh lembaga; sedangkan misi adalah tujuan utama dan sasaran kinerja dari lembaga. Keduanya harus dirumuskan dalam kerangka filosofis, keyakinan dan nilai-nilai dasar yang dianut oleh sekolah yang bersangkutan dan digunakan sebagai konteks pengembangan dan evaluasi atas strategi yang diinginkan.

Sekolah harus mampu menerjemahkan dan menangkap esensi kebijakan makro (pusat) pendidikan serta memahami kondisi lingkungannya (kelebihan dan kekurangannya) untuk kemudian melalui proses perencanaan, sekolah harus memformulasikannya ke dalam kebijakan mikro (sekolah) dalam bentuk program-program prioritas yang harus dilaksanakan dan dievaluasi oleh sekolah yang bersangkutan sesuai dengan visi dan misinya masingmasing. Sekolah harus menentukan target mutu untuk tahun berikutnya. Dengan demikian sekolah secara mandiri tetapi masih dalam kerangka acuan kebijakan nasional dan ditunjang dengan penyediaan input yang memadai, memiliki tanggung jawab terhadap pengembangan sumber daya yang dimilikinya sesuai dengan kebutuhan belajar siswa dan masyarakat juga tidak dapat terlepas dari sistem manajemen. Pada pendidikan terdapat beberapa kelemahan mendasar dalam penyelenggaraan pendidikan di Indonesia, dan kelemahan mendasar itu antara lain yaitu bidang manajemen yang mencakup dimensi proses dan substansi. Pada tataran proses, seperti perencanaan, pengorganisasian, pelaksanaan, dan evaluasi belum dilakukan dengan prosedur kerja yang ketat. Pada tataran substantif, seperti personalia, keuangan, sarana dan prasarana, instrumen pembelajaran, layanan bantu, layanan perpustakaan, 
dan sebagainya, tidak hanya substansinya belum komprehensif, melainkan kriteria keberhasilan untuk masing- masingnya belum ditetapkan secara taat asas (Danim, 2003:6).

Beberapa indikator yang menunjukkan karakter dari konsep manajemen ini antara lain sebagai berikut; (i) lingkungan sekolah yang aman dan tertib, (ii) sekolah memiliki misi dan target mutu yang ingin dicapai, (iii) sekolah memiliki kepemimpinan yang kuat, (iv) adanya harapan yang tinggi dari personel sekolah (kepala sekolah, guru, dan staf lainnya termasuk siswa) untuk berprestasi, (v) adanya pengembangan staf sekolah yang terus menerus sesuai tuntutan IPTEK, (vi) adanya pelaksanaan evaluasi yang terus menerus terhadap berbagai aspek akademik dan administratif, dan pemanfaatan hasilnya untuk penyempurnaan/ perbaikan mutu, dan (vii) adanya komunikasi dan dukungan intensif dari orang tua murid/masyarakat. Pengembangan konsep manajemen ini didesain untuk meningkatkan kemampuan sekolah dan masyarakat dalam mengelola perubahan pendidikan kaitannya dengan tujuan keseluruhan, kebijakan, strategi perencanaan, inisiatif kurikulum yang telah ditentukan oleh pemerintah dan otoritas pendidikan.

Pendidikan ini menuntut adanya perubahan sikap dan tingkah laku seluruh komponen sekolah; kepala sekolah, guru dan tenaga/staf administrasi termasuk orang tua dan masyarakat dalam memandang, memahami, membantu sekaligus sebagai pemantau yang melaksanakan monitoring dan evaluasi dalam pengelolaan sekolah yang bersangkutan dengan didukung oleh pengelolaan sistem informasi yang presentatif dan valid. Akhir dari semua itu ditujukan kepada keberhasilan sekolah untuk menyiapkan pendidikan yang berkualitas/ bermutu bagi masyarakat.

Mutu lulusan tidak terjadi begitu saja, Ia harus direncanakan secara sistematis dengan menggunakan proses manajemen peningkatan mutu lulusan yang diharapkan. Manajemen peningkatan mutu ini meliputi penyusunan perencanaan peningkatan mutu, pengorganisasian, pelaksanaan manajemen peningkatan mutu, serta monitoring dan evaluasi peningkatan 
mutu lulusan. Hal ini didasarkan dengan melihat secara obyektif, tajam dan realistis kondisi- kondisi eksternal dan internal, sehingga dapat mengantisipasi perubahan lingkungan yang akan terjadi. Manajemen peningkatan mutu lulusan yang direncanakan agar output yang dihasilkan mampu bersaing untuk melanjutkan jenjang pendidikan di tingkat Sekolah Menengah Pertama. Hal ini dilakukan karena untuk penerimaan siswa baru ditingkat SMP Negeri dilakukan dengan perangkingan yang standar nilainya telah ditentukan, agar siswa di SDN 2 Pringsewu Barat mampu bersaing dengan sekolah lain maka diperlukan manajemen peningakatan mutu lulusan.

Dari kriteria tesebut maka sekolah dalam meningkatakan mutu lulusannya melakukan manajemen peningkatan mutu lulusan yang di mulai dari perencanaan, pengorganisasiaan, pelaksanaan, monitoring dan evaluasi.

SDN 2 Pringsewu Barat, memiliki latar belakang yang yang beragam dan berbeda-beda baik siswa, orang tua siswa, guru, sarana dan prasarana, serta lingkungannya. Perbedaan-perbedaan inilah yang membuat tertarik untuk melakukan penelitian bagaimana manajemen peningkatan mutu lulusan yang akan dilakukan oleh SDN 2 Pringsewu Barat untuk meningkatkan mutu lulusannya.

Bertitik tolak dari latar belakang masalah tersebut, maka penelitian ini merumuskan masalah sebagai berikut : Secara umum rumusan masalah dalam penelitian ini adalah: "Bagaimana manajemen peningkatan mutu lulusan di SDN 2 Pringsewu Barat?". Secara khusus peneliti merumuskan masalah dalam penelitian ini sebagai berikut: (1) Bagaimana perencanaan peningkatkan mutu lulusan di SDN 2 Pringsewu Barat?; (2) Bagaimana pengorganisasian peningkatkan mutu lulusan di SDN 2 Pringsewu Barat?; (3) Bagaimana pelaksanaa manajemen peningkatan mutu lulusan di SDN 2 Pringsewu Barat?; (4) Bagaimana monitoring dan evaluasi peningkatkan mutu lulusan di SDN 2 Pringsewu Barat?

Penelitian ini secara umum bertujuan untuk mendeskripsikan manajemen mutu lulusan di SDN 2 Pringsewu Barat. Secara Khusus penelitian ini bertujuan untuk 
mendeskripsikan bagaimana: (1) Penyusunan perencanaan untuk meningkatkan mutu lulusan di SDN 2 Pringsewu Barat, (2) Pengorganisasian peningkatkan mutu lulusan di SDN 2 Pringsewu Barat, (3) Pelaksanaa peningkatkan mutu lulusan di SDN 2 Pringsewu Barat, (4) Monitoring dan Mengevaluasi peningkatkan mutu lulusan di SDN 2 Pringsewu Barat.

Penelitian ini diharapkan bermanfaat bagi dunia pendidikan. Manfaat yang penulis harapkan, yaitu: Kegunaan Teoritis yaitu hasil penelitian ini diharapkan memberikan pengetahuan teoritis terhadap pembaca maupun guru dalam upaya meningkatkan mutu lulusan. Dalam mengembangkan ilmu pengetahuan dan tekno- logi khususnya manajemen di SDN 2 Pringsewu Barat untuk peningkatkan mutu lulusan. Kegunaan Praktis yaitu: (1) Menjadi bahan masukan bagi instansi/sekolah lain; (2) Memberikan solusi yang nyata bagi sekolah sebagai upaya untuk meningkatkan mutu lulusan; Memberi masukan kepada pemakai jasa pendidikan (orang tua, siswa dan masyarakat) bagaimana manajemen untuk peningkatan mutu lulusannya.

\section{METODOLOGI PENELITIAN}

Berdasarkan masalah yang telah dijabarkan diatas, maka rancangan penelitian adalah dengan menggunakan metode deskriptif kualitatif. Menurut Dornyei dalam (Noviarini, 2017) mengatakan bahwa the purpose of qualitative research is to provide descriptions of social phenomena which happen naturally. Maksud dari pernyataan tersebut adalah tujuan penelitian kualitatif adalah untuk memberikan penjelasan secara rinci fenomena sosial yang terjadi secara alami.

Subjek dalam penelitian ini adalah Kepala Sekolah, Wakil Kepala Sekolah dan seluruh guru SDN 2 Pringsewu Barat. Teknik pengumpulan data yang akan dilakukan dalam penelitian ini taitu dengan menggunakan observasi, wawancara, dan dokumentasi. Instrumen penelitian adalah peneliti sendiri.

\section{HASIL DAN PEMBAHASAN}

Hasil 


\section{Perencanaan Manajemen}

\section{Peningkatan Mutu Lulusan}

Dalam perencanaan manajemen peningkatan mutu lulusan, SDN 2 Pringsewu barat melakukan dua tahapan, tahap pertama yaitu perencanaan. Pada tahap perencanaan, sekolah melakukan program kerja tahunan yang bertujuan meningkatkan mutu lulusan. Program ini bertujuan untuk perencanaan kerja dalam pembelajaran selama setahun, dengan harapan seluruh pembelajaran selama setahun akan berjalan sesuai harapan dan rencana yang dibuat. Dalam kegiatan pertama pada tahap perencanaan sekolah melakukan rapat dengan orang tua siswa, dewan guru dan komite sekolah mengumpulkan data-data yang merupakan komponen penting dalam persiapan pelaksanaan yaitu data tentang kondisi lingkungan dan ekonomi masyarakat, data tentang sarana dan prasarana yang dimiliki sekolah sebagai penunjang pembelajaran, dan kebutuhan guru sebagai penunjang dalam pembelajaran.

Dari hasil dokumentasi tersebut diperoleh data yang akan dijadikan acuan untuk meningkatkan mutu lulusan di SDN 2 Pringsewu Barat ini. Tahap selanjutnya membuat program kerja, di dalam program kerja juga ditetapkan Visi dan Misi sekolah.

\section{Pengorganisasiaan Manajemen Peningkatan Mutu Lulusan \\ Manajemen Peningkatan Mutu} Lulusan harus terorganisir dengan baik oleh Kepala Sekolah secara langsung, karena dalam pembelajaran di SDN 2 Pringsewu Barat semua guru kelas VI harus berkompeten dalam ilmu yang akan diajarkannya. Selain itu, ijazah S1 harus sesuai dengan pengajarannya. Dalam kegiatan pembelajaran, Kepala Sekolah melakukan berbagai kegiatan yang berhubungan dengan pembelajaran dan berbagai perangkat pendukungnya. Untuk meningkatkan pengetahuan dan kualitas guru kelas VI, Kepala Sekolah selalu mengikutsertakan guru dalam pelatihan-pelatihan yang berkaitan dengan persiapan-persiapan UN dan US. Guru di SDN 2 Pringsewu Barat berjumlah 11 orang guru dan 1 Kepala Sekolah, yang berkualifikasi S-1 berjumlah 9 orang, dan SLTA 2 orang. Pembagian tugas guru yang mengajar sebagai guru kelas sebanyak 9 orang, guru olah raga sebanyak 1 orang, guru 
Pendidikan Agama sebanyak 1 orang, dan guru kesenian sebanyak 1 orang, dan sebagai staf TU 1 orang. Terlihat pada data tidak semua guru di SDN 2 Pringsewu Barat telah berijazah S-1. Namun beberapa orang dari guru yang belum berijazah S-1 saat sekarang sedang mengikuti perkuliah yang diselenggarakan oleh Universitas terbuka (UT) melalui Dinas Pendidikan. Untuk pembagaian tugas guru ini kepala sekolah membuat SK pembagian tugas setiap semester. Selain guru PNS di SDN 2 Pringsewu Barat juga terdapat guru honorer yang bertugas membantu dalam administrasi yang ada disekolah tersebut karena untuk jenjang SD belum ada TU khusus, pengangkatan honorer ini dilakukan kerja sama dengan komite sekolah dalam hal pembiayaan. Sehingga honorer ini dapat membantu tugas-tugas administrasi, tugas guru hanya diperuntukan dalam pembelajaran.

\section{Pelaksanaan}

Manajemen

\section{Peningkatan Mutu Lulusan}

Dalam kegiatan pembelajaran di SDN 2 Pringsewu Barat memerlukan perencanaan pembelajaran yang optimal, disebabkan mutu lulusan yang diharapkan dapat tercapai dengan baik. Manajemen Peningkatan Mutu Lulusan diupayakan dengan melengkapi perangkat pembelajaran sesuai dengan kurikulum yang berlaku agar proses pembela-

meningkatkan mutu lulusan di SDN 2 Pringsewu Barat pihak sekolah melalui pemerintah setempat maupun dari dana BOS dan kerjasama dengan komite sekolah melengkapi Fasilitas yang diberikan pada siswa untuk menunjang mutu lulusan yaitu perpustakaan yang dilengkapi bukubuku penunjang pembelajaran, Alat peraga dan proyektor.

Perangkat pembelajaran dengan didukung alat peraga dan fasilitas pendukung Kegiatan pembebelajaran yang lengkap dimanfaatkan dan disusun secara baik akan menjadi jaminan separuh kegiatan yang berhasil dilaksanakan, bagi seorang pendidik menyusun kegiatan pembelajaran yang benar-benar sesuai dengan kebutuhan anak. Karena itulah dalam kegiatan pembelajaran harus lebih bermakna yang pada akhirnya diharapkan dapat meningkatkan mutu pembelajaran pada 
prosesnya dan out put yang dihasilkan akan bermutu.

\section{Monitoring dan Evaluasi} Manajemen Peningkatan Mutu

\section{Lulusan}

Pengawasan dan evaluasi merupakan salah satu fungsi dalam manajemen yaitu sebagai alat pengendalian/kontrol terhadap pelaksanaan kegiatan untuk mengetahui tingkat ketercapaian dari kegiatan pembembelajaran yang telah direncanakan dalam upaya mencapai tujuan program yang diharapkan.

Evaluasi dilakukan untuk melihat keberhasilan dan kelemahan secara totalitas program peerencanaan, pelaksanaan, hasil yang diperoleh dan dampak dari adanya program. Hasil evaluasi ini dapat digunakan untuk melakukan perbaikan dan tindak lanjut dalam perencanaan pada program berikutnya.

Kepala Sekolah selaku manajer melakukan monitoring dan evaluasi untuk melihat dan mengetahui bagaimana pelaksanaannya, kekurangan atau kendala yang dihadapi.

Secara teknis SDN 2 Pringsewu Barat merupakan bagian dari pendidikan dasar dimana pemerintah telah mencanangkan wajib belajar 9 tahun, yaitu di sekolah dasar 6 tahun dan menengah 3 tahun. Pengawasan dilakukan oleh pengawas TK/SD dalam proses pembelajarannya dan administrasinya. Pengawasan ini menggunakan instrumen yang baku yang dirancang oleh Kemendikbud. Laporan pengawasannya disampaikan ke Dinas Pendidikan Kabupaten Pringsewu Barat. Namun dalam hal ini yang melakukan pengawasan terhadap manajemen mutu lulusan di SDN 2 Pringsewu Barat jarang berlangsung dengan maksimal. Perangkat pembelajaran seperti Kurikulum, Program Tahunan, semester, Silabus, dan RPP serta dengan media pembelajaran yang dalam KBM. Untuk membuat pembelajaran tersebut guru memiliki forum, yaitu Kelompok Kerja Guru (KKG).

Dalam pelaksanaannya untuk meningkatkan mutu lulusan perangkat pembela- jaran sangat membantu dan mendukung tercapainya Visi dan Misi sekolah. Untuk meningkatkan mutu lulusan di SDN 2 Pringsewu Barat pihak sekolah melalui pemerintah 
setempat maupun dari dana BOS dan kerjasama dengan komite sekolah melengkapi Fasilitas yang diberikan pada siswa untuk menunjang mutu lulusan antara lain perpustakaan yang dilengkapi buku-buku penunjang pembelajaran, Alat peraga dan Proyektor.

Perangkat pembelajaran dengan didukung alat peraga dan fasilitas pendukung Kegiatan pembembelajaran yang lengkap dimanfaatkan dan disusun secara baik akan menjadi jaminan separuh kegiatan yang berhasil dilaksanakan, bagi seorang pendidik menyusun kegiatan pembelajaran yang benar-benar sesuai dengan kebutuhan anak. Karena itulah dalam kegiatan pembelajaran harus lebih bermakna yang pada akhirnya diharapakan dapat meningkatkan mutu pembelajaran pada prosesnya dan output yang dihasilkan akan bermutu.

\section{Monitoring dan Evaluasi Manajemen Peningkatan Mutu \\ Lulusan}

Pengawasan dan evaluasi merupakan salah satu fungsi dalam manajemen yaitu sebagai alat pengendalian terhadap pelaksanaan kegiatan untuk mengetahui tingkat ketercapaian dari kegiatan pembembelajaran yang telah direncanakan dalam upaya mencapai tujuan program yang diharapkan.

Evaluasi dilakukan untuk melihat keberhasilan dan kelemahan secara totalitas program perencanaan, pelaksanaan, hasil yang diperoleh dan dampak dari adanya program. Hasil evaluasi ini dapat digunakan untuk melakukan perbaikan dan tindak lanjut dalam perencanaan pada program berikutnya.

Kepala Sekolah selaku manajer melakukan monitoring dan evaluasi untuk melihat dan mengetahui bagaimana pelaksanaannya, kekurangan atau kendala-kendala yang dihadapi.

Secara teknis SDN 2 Pringsewu Barat merupakan bagian dari pendidikan dasar dimana pemerintah telah mencanangkan wajib belajar 9 tahun, yaitu di sekolah dasar 6 tahun dan menengah 3 tahun. Pengawasan dilakukan oleh pengawas TK/SD dalam proses pembelajarannya dan administrasinya. Pengawasan ini menggunakan instrumen yang baku yang dirancang oleh Kemendikbud. 
Laporan pengawasannya disampaikan ke Dinas Pendidikan Kabupaten Pringsewu Barat. Namun dalam hal ini yang melakukan pengawasan terhadap manajemen mutu lulusan di SDN 2 Pringsewu Barat adalah kepala sekolah, yang melibatkan pengawas sekolah, unsur terkait seperti orang tua siswa dan komite sekolah. Pengawasan dilakukan agar Visi dan Misi Sekolah dapat tercapai dan program yang telah dibuat dapat terlaksana dan berhasil sesuai harapan.

Pengawasan secara umum mencakup manajemen dan pembelajaran. Aspek manajemen mengacu pada Visi dan Misi, Program kerja tahunan jangka pendek, menengah dan jangka panjang. Pengawasan sebagai bagian dari integral dalam peningkatan mutu lulusan.

Untuk itu perlu diadakan pengawasan dan pembinaan secara rutin dengan media KKG (Kelompok Kerja Guru). Kegiatan yang diselenggarakan melalui pertemuan secara berkala, selain untuk meningkatkan kapasitas SDM guru juga untuk meningkatkan mutu pembelajaran dan motivasi belajar anak.
Dalam Visi dan Misi sekolah, program kerja tahunan sekolah memiliki target bagi siswa yang lulus, yaitu mampu bersaing disekolah- sekolah favorit dan sekolah-sekolah negeri yang dianggap unggul. Apalagi untuk ukuran SDN 2 Pringsewu Barat mutu lulusan diharapkan mampu bersaing di SMPN yang ada di kota Pringsewu.

Berdasarkan hasil wawancara, tergambar bahwa kegiatan Pengawasan yang dilakukan baik oleh pengawas TK/SD maupun Kepala Sekolah dalam pembelajaran telah cukup sesuai dengan perencanaan yang dibuat.

\section{Pembahasan}

\section{Perencanaan Manajemen}

\section{Peningkatan Mutu Lulusan}

Taufiqurokhman

(2008) mengatakan Perencanaan adalah suatu proses menentukan apa yang ingin dicapai pada masa yang akan datang serta menetapkan tahapan-tahapan yang dibutuhkan untuk mencapainya. Dengan demikian,proses perencanaan dilakukan dengan menguji berbagai arah pencapaian serta mengkaji berbagai ketidakpastian yang ada, mengukur kemampuan (kapasitas) kita untuk 
mencapainya kemudian memilih araharah dan langkah-langkah terbaik untuk mencapainya. Rencana dapat berupa rencana informal atau rencana formal.

Untuk pencapaian suatu target tertentu dibuatkan perencanaan, perencanaan merupakan proses manajerial dalam menentukan apa yang akan dikerjakan dan bagaimna mengerjakannya. Dalam perencanaan digariskan tujuan-tujuan yang akan dicapai dan dikembangkan dalam bentuk program kerja untuk mencapai tujuan tersebut. Burhanudin (1994:10) menyatakan bahwa perencanaan adalah aktivitas pengambilan keputusan tentang sasaran yang akan dicapai, tindakan yang akan diambil dalam rangka mencapai sasaran tersebut dan pihak- pihak yang akan melaksanakan tugas tersebut. Dalam perencanaan di SDN 2 Pringsewu Barat membuat program perencanaan dengan langkah sebagai berikut : menyusun Visi, Misi dan tujuan Sekolah, menyusun program kerja tahunan, menengah, dan panjang, menyusun anggaran dan jadwal kegiatan. Untuk menyusun Visi dan Misi sekolah, program peningkatan mutu lulusan dilakukan melalui rapat yang melibatkan orang tua siswa dan komite sekolah. Syaiful Sagala (2010:15) menjelaskan bahwa visi merupakan suatu proses yang menggambarkan serangkaian kegiatan perencanaan dan penetapan sasaran dalam aktivitas organisasi seperti satuan pendidikan masing-masing. Visi bagi lembaga pendidikan dalam sebuah organisasi sangat dibutuhkan, untuk itu visi yang dimaksud adalah model masa depan organisasi yang menjadi komitmen dan milik bersama seluruh anggota organisasi. Dalam suatu organisasi, pasti ada visi dan misinya. Sekolah, misalnya, biasanya mencantumkan visi dan misinya di gerbang masuk yang dicetak besar agar mudah dibaca oleh perangkat sekolah, wali, dan masyarakat. Visi Misi sebagai identitas dan suatu kebanggaan yang menunjukkan ke mana arah sekolah tersebut menuju. Output seperti apa yang diharapkan, dan proses bagaimana yang dijalankan. Misi adalah "what be believe we can do"

Dari hasil penelitian di SDN 2 Pringsewu Barat bahwa sekolah masin tergolong baru dalam menetapkan program manajemen peningkatan mutu 
lulusan ini sehingga hasil yang diharapkan belum begitu terlihat nyata. Untuk melihat hasil nyata seperti yang diharapkan membutuhkan jangka waktu yang panjang.

\section{Pengorganisasian Manajemen Peningkatan Mutu Lulusan}

Dari hasil penelitian di lapangan memang untuk penempatan guru dan staf dalam pembagian tugas sudah sesuai dengan kualifikasi jenjang pendidikan S-1 namun bidang yang di ampuh bukan khusus untuk SD sedangkan seharusnya guru SD itu memiliki kualifikasi pendidikan S-1 PGSD. Guru kelas VI di SDN 2 Pringsewu Barat memiliki kualifikasi pendidikan S-1 dengan jurusan Bahasa Indonesia yang mana merupakan guru bidang studi saja bukan bidangnya guru kelas. Dalam aturan sertifkasi juga dijelaskan bahwa guru yang bersertifikasi di SD wajib memiliki ijazah S-1 PGSD, menurut Kementerian Pendidikan dan Kebudayaan (Kemendikbud) mewajibkan guru Sekolah Dasar (SD) memiliki ijazah PGSD (Pendidikan Guru Sekolah Dasar) untuk mendapatkan tunjangan profesi pendidik (TPP). Bagi guru SD yang belum mimiliki ijazah PGSD harus segera kuliah lagi.

Undang-undang Nomor 20 Tahun 2003 Tentang Sistem Pendidikan Nasional dan Undang-undang Nomor 14 Tahun 2005 tentang Guru dan Dosen menyatakan bahwa guru sebagai pendidik merupakan tenaga profesional.

Dalam Undang-undang Nomor 14 Tahun 2005 tentang Guru dan Dosen. Peraturan menteri pendidikan nasional Nomor 16 tahun 2007 Tanggal 4 mei 2007 Standar kualifikasi akademik dan kompetensi guru. Kualifikasi Akademik Guru SD/MI Guru pada SD/MI, atau bentuk lain yang sederajat, harus memiliki kualifikasi akademik pendidikan minimum diploma empat (D-IV)atau sarjana (S1) dalam bidang pendidikan SD/MI (D-IV/S1 PGSD/ PGMI) psikologi yang diperoleh dari program studi yang terakreditasi.

SDN 2 Pringsewu Barat sebagai lembaga pendidikan sekolah sesuai dengan Visi dan Misinya perlu bertindak proaktif dalam proses dan kegiatan untuk memajukan dan meningkatkan mutu lulusan, hal tersebut merupakan tanggung jawab 
semua pihak dan tanggung jawab utama dari kepala sekolah.

Hasil penelitian menunjukkan bahwa SDN 2 Pringsewu Barat telah melakukan tahap-tahap kegiatan yang direncanakan seperti membuat jadwal les untuk tiga mata pelajaran yang di UN kan.

Perbandingan teori tersebut dengan hasil penelitian menunjukkan bahwa pengorganisasian belum sepenuhnya sesuai dengan aturan yang ada. Dalam Undang-undang Nomor 14 Tahun 2005 tentang Guru dan Dosen. Peraturan menteri pendidikan nasional Nomor 16 tahun 2007 Tanggal 4 Mei 2007 Standar kualifikasi akademik dan kompetensi guru. Kualifikasi akademik Guru SD/MI Guru pada SD/MI, atau bentuk lain yang sederajat, harus memiliki kualifikasi akademik pendidikan minimum diploma empat (D-IV)atau sarjana (S1) dalam bidang pendidikan SD/MI (D-IV/S1 PGSD/ PGMI) psikologi yang diperoleh dari program studi yang terakreditasi. Hal ini menjadi dasar

bagi kepala sekolah dalam menempatkan guru dan stafnya sesuai dengan kualifikasi pendidikan dan bidangnya masing-masing.

\section{Pelaksanaan Manajemen \\ Peningkatan Mutu Lulusan}

Program kerja yang telah dibuat dalam perencanaan kemudian diimplementasikan dalam pelaksanaan melalui pembelajaran. Pelaksanaan adalah proses dilakukan dan digerakkannya perencanaan. Fungsi pelaksanaan merupakan proses manajemen untuk merealisasikan.

Dari hasil penelitian didapat bahwa SDN 2 Pringsewu Barat memakai Kurikulum Tingkat Satuan Pendidikan (KTSP). Dalam Standar Nasional Pendidikan (SNP Pasal 1, ayat 15) dikemukakan bahwa Kurikulum Tingkat Satuan Pendidikan (KTSP) adalah kurikulum operasional yang disusun dan dilaksanakan oleh masingmasing satuan pendidikan. Penyusunan KTSP dilakukan oleh satuan pendidikan dengan memperhatikan dan berdasarkan standar kompetensi serta kompetensi dasar yang dikembangkan oleh Badan Standar Nasional Pendidikan (BSNP).

Hasil penelitian menunjukkan semua guru di SDN 2 Pringsewu Barat telah membuat perangkat pembelajaran 
dengan baik. Menurut Cyntia dalam Mulyasa (2006) bahwa setiap guru dalam satuan pendidikan berke- wajiban menyusun rencana pelaksanaan pembelajaran secara lengkap dan sistematik agar pembelajaran yang berlangsung dapat terarah dan terkendali.

\section{Arikunto}

(1993:12),

mengemukakan "pembelajaran adalah suatu kegiatan yang mengandung terjadinya proses penguasaan pengetahuan, keterampilan dan sikap oleh subjek yang sedang belajar".

Dalam

pelaksanaannya manajemen peningkatan mutu lulusan di SDN 2 Pringsewu Barat ini belum maksimal hal ini terlihat dari kehadiran siswa dalam kegiatan les dikarenakan siswa tersebut malas untuk datang atau ada yang membantu orang tuanya, itu artinya juga belum adanya sikap proaktif orang tua dalam mendukung kegiatan yang di programkan oleh sekolah. Pentingnnya kehadiran siswa tidak lain karena para siswa terutama kelas VI akan menghadapi UN.

\section{Monitoring dan Evaluasi}

Manajemen Peningkatan Mutu

\section{Lulusan}

Pengawasan secara teknis merupakan bagian dari pendidikan pengawasan dilakukan oleh pengawas TK/SD yang bertugas melakukan pengawasan dan penilaian terhadap satuan pendidikan Sekolah Dasar.

Monitoring dan evaluasi dalam satuan pendidikan merupakan bagian yang terpenting dalam sebuah instansi/sekolah. Cornor (1974), menjelaskan bahwa keberhasilan dalam mencapai tujuan, separuhnya ditentukan oleh rencana yang telah ditetapkan dan setengahnya adalah dari fungsi pengawasan. Pada umumnya, manajemen menekankan terhadap pentingnya kedua fungsi ini, yaitu perencanaan dan pengawasan. Hal ini didasari oleh adanya pemikiran bahwa dengan menggunakan peman- tauan dan penilaian dapat diukur tingkat kemajuan dan keberhasilan program pendidikan dari sekolah baik tingkat kecamatan maupun tingkat Kabupaten/Kota hingga ke tingkat Provinsi dan selanjutnya. Hal ini dapat diguna- kan untuk menghasilkan informasi guna mendukung pengambilan keputusan.

Dengan adanya informasi tersebut diharapkan dalam strategi 
pengelolaannya harus dilakukan dengan tepat. Monitoring sendiri adalah sebuah kegiatan untuk mendapat informasi tentang pelaksanaan dari penerapan kebijakan sehingga dapat disimpulkan bahwa fokus dari pada monitoring itu sendiri berdasar- kan pada pelaksanaannya bukan berdasarkan hasil.

Berdasarkan hasil penelitian pengawasan manajemen peningkatan mutu lulusan di SDN 2 Pringsewu Barat menunjukkan bahwa terlihat pengawasan hanya dilakukan oleh kepala sekolah, sementara orang tua dan komite sekolah belum ikut melakukan pengawasan hal ini dikarenakan mungkin mereka merasa bukan unsur yang terkait dalam pengawasannya.

Sementara itu evaluasi adalah proses untuk mendapatkan informasi tentang hasil, dimana informasi ini dibandingkan dengan sasaran atau target yang telah ditetapkan. Jika hasilnya sesuai dengan sasaran atau target yang telah ditetapkan. Jika hasilnya sesuai berarti apa yang telah ditetapkan berhasil atau efektif namun apabila sebaliknya maka evaluasi tersebut dianggap tidak efektif/gagal.
Monitoring dan evaluasi ini bertujuan untuk mendapatkan informasi yang digunakan untuk pengambilan keputusan. Hasil dari monitoring akan digunakan untuk memberikan binaan masukan (umpan balik), bagi perbaikan pelaksanaan program, sedangkan hasil dari evaluasi dapat memberikan informasi yang dapat digunakan untuk memberikan masukan-masukan terhadap keseluruhan komponen.

Hasil penelitian menunjukkan bahwa SDN 2 Pringsewu Barat selama menerapkan manajemen peningkatan mutu lulusan ini telah melakukan pengukuran dengan menilai kegiatan yang dilakukan oleh guru kelas VI. Penilaian dilakukan melalui kegiatan monitoring oleh kepala sekolah baru satu kali di akhir tahun ajaran 2013/2014. Dari hasil monitoring di tahun ajaran 2013/2014 didapat bahwa dari 21 siswa kelas VI yang dapat masuk ke Sekolah Menengah Pertama Negeri sebanyak 19 orang itu menunjukkan bahwa 90, 47\% siswa telah dapat masuk sekolah negeri seperti yang diharapkan. Untuk itu evaluasi sangat diperlukan dalam menindak lanjuti hasil dari pelaksanaan 
manajemen yang ada di suatu lembaga seperti di SDN 2 Pringsewu Barat.

\section{KESIMPULAN}

Kesimpulan dalam penelitian ini secara umum bahwa manajemen peningkatan mutu lulusan disesuaikan dengan kemampuan dan keterbatasan sekolah terutama dari pelaksanaan, tata kelola program tahunan dan pengendalian penunjang pembelajaran serta pengawasan, dengan mempertimbangkan keadaan lingkungan dan kondisi daerah setempat. Secara khusus, simpulan yang dapat diambil oleh peneliti dari hasil penelitian ini adalah sebagai berikut:

1. Perencanaan peningkatan mutu lulusan SDN 2 Pringsewu Barat, yaitu meliputi : (a) pihak sekolah mengadakan kerja sama dengan orang tua siswa dan komite sekolah untuk proses perencanaan, (b) Pembelajaran pada jam tambahan telah ditetapkan oleh pihak sekolah, (c) administrasi untuk kegiatan siswa ditanggung oleh pihak sekolah, (d) sarana dan prasaran menunjang pembelajaran;

2. Pengorganisasian manajemen peningkatan mutu lulusan ini terlihat dalam pembagian tugas guru dalam pembela- jaran;

3. Pelaksanaan peningkatan mutu lulusan meliputi sarana dan prasarana, fasilitas yang mendukung proses pembelajaran, perangkat pembelajaran yang terdiri dari Kurikulum Tingkat Satuan pendidikan (KTSP), Program Tahunan, Prgoram Semester, Silabus dan RPP.;

4. Monitoring dan evaluasi manajemen peningkatan mutu lulusan secara teknis dilakukan oleh pengawai Sekolah dan masyarakat. Pengawasan oleh Kepala Sekolah dilakukan dua kali dalam satu tahunan dengan mengevaluasi hasil lulusan yang diterima di sekolah pilihan dan sekolah-sekolah negeri.

\section{DAFTAR PUSTAKA}

Arikunto, Suhaimi. (2010). Manajemen Pendidikan. Jakarta: Rineka Cipta.

Burhanuddin, Afid. (2014). Pengertian, fungsi, dan Ruang Lingkup Manajemen

Pendidikan.http://afidburhanuddin .wordpr ess.com/2014/01/17/pengertianfungsi- dan-ruang-lingku- 
manajemen-pendidikan/ (diunduh tanggal 05 Desember 2014)

Conor. (1974). Monitoring Pekerjaan. Yogyakarta: Nur Cahaya

Crow, L.D. \& Alice C. (1989). Psycology Pendidikan. Terjemahan Abd. Rachman Abror. Education Psycologi. Yogyakarta: Nur Cahaya

Daft, L, Richard. (2006). Perencanaan Pendidikan: Suatu Pendekatan Komprehensif. Bandung: Remaja Rosdakarya.

Danim, Sudarwan. (2002). Menjadi Peneliti Kualitatif. Bandung: Pustaka Setia
Dharma, Agus. (2004). Manajemen Supervisi (Petunjuk Praktis Bagi Para Supervisor). Jakarta : Raja Grafindo Persada.

Noviarini, T. (2017). TECHNIQUES IN TEACHING VOCABULARY AT THE FIRST GRADE SD CITRA BANGSA SCHOOL PRINGSEWU. STKIP Muhammadiyah Pringsewu, Vol 3, No2.

Taufiqurokhman. (2008). Konsep dan Kajian Ilmu Perencanaan (R. Joewis, ed.). Jakarta: Fakultas Ilmu Sosial dan Ilmu Politik Universitas Prof. Dr. Moestopo Beragama. 